\title{
Enzymatic Improvement of Food Flavor III. Oxidation of the Soybean Protein-Bound Aldehyde by Aldehyde Dehydrogenase
}

\author{
Hideo Chiba, Naofumi Takahashi, Noriko Kitabatake \\ and Ryuzo SASAKI \\ Department of Food Science and Technology, Faculty of Agriculture, \\ Kyoto University, Kyoto 606, Japan \\ Received March 29, 1979
}

\begin{abstract}
Defatted soybean extract was fractionated into protein fractions and low molecular weight fractions with gel filtration. NAD-dependent aldehyde dehydrogenase from bovine liver mitochondria and from yeast was found to oxidize aldehyde in both fractions. These enzymes, therefore, were used to determine the quantity of aldehyde. When the protein fraction obtained by gel filtration was subjected to gel filtration again, aldehyde was recovered in the protein fractions. The level of aldehyde in the protein fractions was unchanged before and after digestion of the protein with pepsin. When the soybean extract was incubated beforehand with aldehyde dehydrogenase and $\mathrm{NAD}^{+}$and the subjected to gel filtration, no aldehyde was detected in the protein fractions. These results indicate that aldehyde dehydrogenase acts on the soybean protein-bound aldehyde. Alcohol dehydrogenase from horse liver in the presence of NADH did not convert the bound aldehyde to alcohol.

A large portion of the aldehyde in the extract was separated from the protein by acid precipitation of the protein. Aldehyde dehydrogenase acts on the aldehyde remaining in the protein after acid precipitation. Thus acid precipitation helps to save $\mathrm{NAD}^{+}$required for complete removal of aldehyde from the soybean protein by aldehyde dehydrogenase.
\end{abstract}

In the effort to improve food flavor, the interaction between proteins and a number of flavor components, including aldehydes, has been investigated. ${ }^{1 \sim 3)}$ Soy-protein isolate as well as soy-protein concentrate contains firmly bound aldehydes which are resistant to extraction under usual conditions, but which are released by proteolytic digestion of the protein. ${ }^{4,5)}$ The gradual release of bound aldehyde during the storage and cooking of soybean products develops an off-flavor.

In the first paper of this series, we reported the occurrence of aldehyde dehydrogenase (ALDH) in bovine liver mitochondria with high affinities to various kinds of aldehydes. ${ }^{6}$ In the second paper, we showed the successful use of the purified ALDH for removing the objectionable green beany flavor due to aldehydes in soybean extract and in other foods. ${ }^{7}$ Beany flavor did not develop in soy-protein

Abbreviations: ALDH, aldehyde dehydrogenase: $\mathrm{ADH}$, alcohol dehydrogenase. isolate prepared after treatment with $\mathrm{ALDH},{ }^{\text {?) }}$ which suggested that ALDH might act on protein-bound aldehydes. We report here evidence that ALDH does oxidize aldehydes bound to soybean protein. The present work is also aimed at getting further insight into the interaction between proteins and flavor compounds. Preliminary reports of this work have appeared. ${ }^{8,9)}$

\section{MATERIALS AND METHODS}

Pepsin was purchased from Nakarai Co., Ltd. Defatted soybean flakes were a gift from Fuji Oil Co., Ltd. Other materials were as in the accompanying paper. ${ }^{8,7)}$ Bovine liver mitochondrial ALDH was used, unless otherwise indicated. Purification of the enzyme and the definition of the enzyme unit were as described before. ${ }^{\text {) }}$

Soybean extract. The defatted soybean extracts were prepared as follows. Defatted soybean flour was suspended in 10-fold $20 \mathrm{~mm}$ phosphate buffer, $\mathrm{pH} 7.5$ $(1: 10 \mathrm{w} / \mathrm{v})$ or in 5 -fold buffer $(1: 5 \mathrm{w} / \mathrm{v})$. After the 
suspension was stirred for $30 \mathrm{~min}$, it was centrifuged at $12,000 \times g$ for $10 \mathrm{~min}$. The supernatant was used as soybean extract. The extract was prepared on the day of experiment.

Preparation of the soybean protein solution by acid precipitation. The soybean extract was acidified to pH 4.5 with $6 \mathrm{~N} \mathrm{HCl}$ to precipitate the protein. After standing for $15 \sim 30 \mathrm{~min}$, the extract was centrifuged at $10,000 \times g$ for $10 \mathrm{~min}$. The precipitate was dissolved in distilled water by the gradual addition of $6 \mathrm{~N} \mathrm{NaOH}$ and the volume of the solution was made the same as the original one with distilled water. When precipitation was conducted repeatedly, the protein solutions of each precipitation were prepared by the same procedure.

Digestion of the soybean protein with pepsin. Digestion of the soybean protein with pepsin was measured by following the increase in $5 \%$ trichroloacetic acidsoluble peptides. The soybean protein solution was acidified to $\mathrm{pH} 1.6$ with $\mathrm{HCl}$, and then pepsin dissolved in $0.01 \mathrm{M} \mathrm{HCl}$ was added. The conditions for incubation were described in legends of the figures and the tables. The reaction was terminated with the addition of $25 \%$ trichroloacetic acid to a final concentration of $5 \%$. After centrifugation, peptide in the supernatant was measured by the ninhydrin method. ${ }^{10)}$

Measurement of aldehyde with ALDH. Aldehyde was measured enzymatically with ALDH. The reaction mixture contained, in a total volume of $3.0 \mathrm{ml}$, $100 \mathrm{~mm}$, pyrophosphate buffer, pH $9.3,0.3 \mathrm{~mm}$ $\mathrm{NAD}^{+}, 3.3 \mathrm{~mm}$ pyrazole, the sample, and ALDH. Pyrazole was added to inhibit ADH activity in the soybean extract. When yeast ALDH was used, $\mathrm{KCl}$ was added for a final concentration of $100 \mathrm{~mm}$. The reaction was followed by measuring the increase in absorbancy at $340 \mathrm{~nm}$ with a Shimadzu double-beam spectctrophotometer, a model UV-200, equipped with a recorder. The temperature was $25^{\circ} \mathrm{C}$. The reaction was allowed to proceed until a plateau was reached (see Fig. 5) and aldehyde was calculated from the increase in absorbancy, using a molecular extinction coefficient of NADH $\left(6.22 \times 10^{3} \mathrm{M}^{-1} \mathrm{~cm}^{-1}\right)$. When the soybean protein was digested with pepsin, the reaction mixture for digestion was neutralized before determination of aldehyde.

The protein was measured by the method of Lowry et al. ${ }^{11}$ )

Unless otherwise specified, all procedures were carried out at room temperature $\left(15 \sim 20^{\circ} \mathrm{C}\right)$,

\section{RESULTS}

Effect of aldehyde dehydrogenase and alcohol dehydrogenase on aldehyde in defatted soybean extracts
To quantify aldehydes in soybean extracts, standard curves in the presence and absence of the soybean protein were drawn using nhexanal and bovine mitochondrial ALDH. As shown in Fig. 1, quantification of $n$-hexanal in the absence of soybean protein gave a linear line crossing the origin of the coordinate axis. Although the soybean protein solution was prepared by passing the soybean extract through a Sephadex G-50 column, and thus the free aldehyde in the extract was completely removed, the standard curves in the presence of the soybean protein did not cross the origin, but were straight lines parallel to the one made in the absence of the soybean protein. The amount of aldehyde detected in the gel-filtered soybean extract was proportional to that of the soybean protein added. These results suggest that there is protein-bound aldehyde which is oxidized by ALDH. Or it is possible that the protein-bound aldehyde and the free aldehyde which dissociated from the protein after gel filtration are at equilibrium and that ALDH acts on the free aldehyde, but not on the

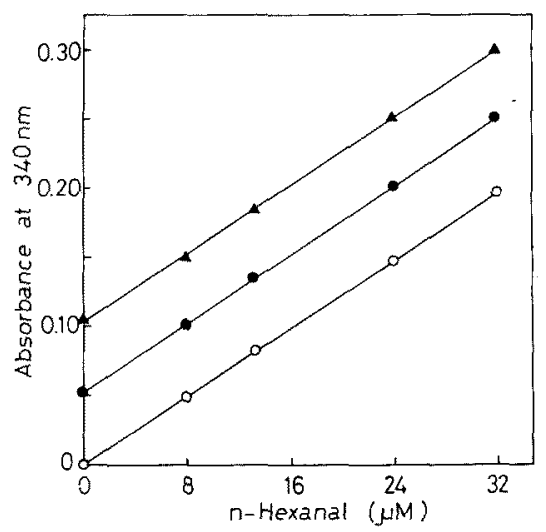

Fig. 1. Standard Curves for Aldehyde Measurement in the Presence and Absence of Soybean Protein.

Standard curves for enzymatic measurement of aldehyde were drawn, using $n$-hexanal. Aldehyde was measured spectrophotometrically as described in Materials and Methods. (O) refers to the absence and $(\mathbf{\Lambda})$ to the presence of soybean protein. Soybean protein solution was prepared by passing the extract through a Sephadex G-50 column (see legend of Fig. 2). $0.03 \mathrm{ml}(\bullet)$ or $0.06 \mathrm{ml}(\Delta)$ of the protein fraction $(33 \mathrm{mg} / \mathrm{ml})$ was added to the reaction mixtures for measuring aldehyde. 


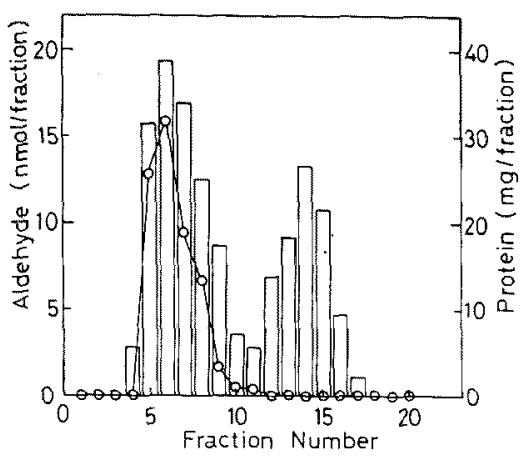

Fig. 2. Gel Filtration of the Soybean Extract. $1.0 \mathrm{ml}$ of the defatted soybean extract $(1: 5 \mathrm{w} / \mathrm{v})$ was passed through a Sephadex G-50 column $(1 \times 30 \mathrm{~cm})$ equilibrated with $20 \mathrm{~mm}$ phosphate buffer $\mathrm{pH} 7.5$. The flow rate was $0.5 \mathrm{ml} / \mathrm{min}$, and $3 \mathrm{ml}$ fractions were collected. Aldehyde and protein in each fraction were measured as described in Materials and Methods. A line graph is protein concentration (mg/fraction) and a bar graph is aldehyde concentration (nmol/ fraction).

\section{bound form.}

To decide this issue, defatted soybean extract $(1: 5 \mathrm{w} / \mathrm{v})$ was subjected to gel filtration, and then aldehyde in each fraction was measured with ALDH. Figure 2 shows that aldehyde was found in protein fractions as well as in low molecular weight fractions. Rechromatography of the protein fraction (fraction number 6 in Fig. 2) resulted in the recovery of aldehyde in protein fractions (Fig. 3). Similar results were obtained with extract (1: $10 \mathrm{w} / \mathrm{v})$ prepared by using 10 volumes of the extraction buffer per weight of defatted soybean flour (data not shown). Gel filtration was carried out at $\mathrm{pH} 7.5$, while aldehyde was measured at $\mathrm{pH} 9.3$ optimal for ALDH activity. It might be argued, therefore, that the aldehyde protein complexes dissociate at pH 9.3 and ALDH acts on the dissociated aldehydes but not on the bound form. This possibility, however, was excluded by the finding of aldehyde in the protein fractions when extract was subjected to gel filtration at $\mathrm{pH} 9.3$ (data not shown). When the extract $(1: 5$ w/v) was incubated beforehand with 0.15 unit/ml ALDH, $5 \mathrm{mM} \mathrm{NAD}^{+}$at $25^{\circ} \mathrm{C}$ for 60 min and then the reaction mixture was subjected to gel filtration, no aldehyde was found in

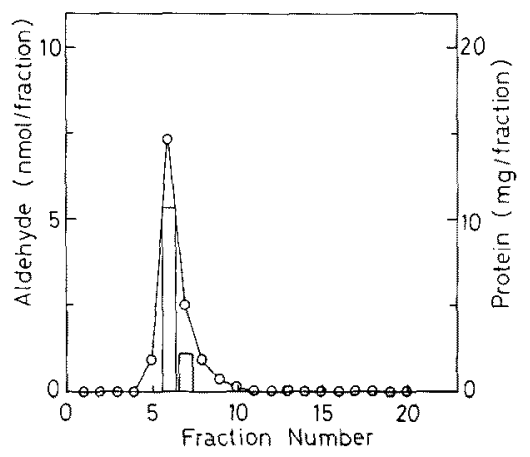

Frg. 3. Rechromatogram of the Protein Fraction. The protein fraction (1.5 ml of fraction number 6$)$ in Fig. 2 was rechromatographed with the same procedures as for Fig. 2. A line graph is protein concentration (mg/fraction) and a bar graph is aldehyde concentration (nmol/fraction).

the protein fractions (data not shown). It seems very likely from these results that ALDH can oxidize aldehyde so firmly bound to the soybean protein as to be undissociable during gel filtration. Amounts of both free and protein-bound aldehydes in the soybean extract was calculated by summing the aldehyde in protein fractions and in low molecular weight fractions on the gel filtration chromatograms, respectively. Table I shows the results. The amount of the bound aldehyde was about $65 \%$ of the total aldehyde in the extract. It was calculated that the soybean protein binds approximately $1.2 \mu \mathrm{mol}$ of aldehyde per $g$ of

Table I. Aldehyde In the Defatted Soybean ExTRACT

The protein-bound and free aldehydes were calculated by summing aldehyde in the protein fractions (fraction number $4 \sim 10$ ) and in the low molecular weight fractions (fraction number $11 \sim 17$ ) in Fig. 2, respectively. Although the gel filtration pattern for the extract $(1: 10 \mathrm{w} / \mathrm{v})$ is not shown, aldehyde was calculated in the same manner as in the extract (1:5 w/v).

\begin{tabular}{|c|c|c|c|}
\hline \multirow{2}{*}{ Extracts } & \multicolumn{2}{|c|}{ Aldehyde (nmol) ${ }^{a}$} & \multirow{2}{*}{$\begin{array}{l}\text { Bound } \\
\text { aldehyde } \\
\text { per g of } \\
\text { protein } \\
\text { ( } \mu \text { mol) }\end{array}$} \\
\hline & Bound & Free & \\
\hline 1:5 Extract & 79.5 & 49.2 & 1.03 \\
\hline 1: 10 Extract & 37.0 & 18.0 & 1.30 \\
\hline
\end{tabular}

a per $1.0 \mathrm{ml}$ of the appropriate extract. 
protein. These values varied somewhat from experiment to experiment, probably depending on vaporization of the free aldehyde during experiments. They also varied from sample to sample, possibly depending on the soybeans from which the extracts were prepared and on the conditions under which the soybean was defatted.

Enzymatic oxidation rates were compared among free $n$-hexanal, soybean protein-bound aldehyde, and aldehyde in the soybean extract (Fig. 4). The gel-filtered extract was used as the sample containing bound aldehyde. In all cases the aldehyde concentration in the reaction mixture was adjusted to the same level. ALDH oxidizes bound aldehyde with a rate approximately half of that for free $n$-hexanal. It is interesting that the aldehyde in the extract

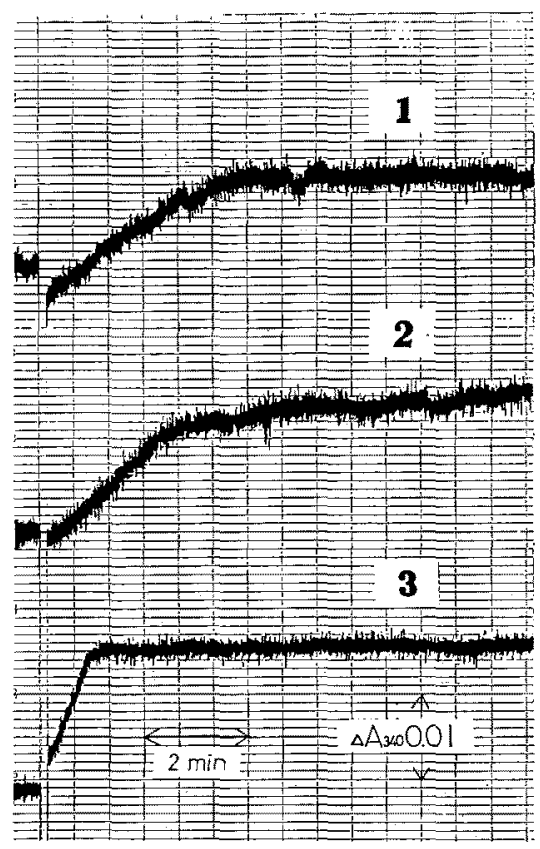

FIG. 4. Enzymatic Oxidation Rates of Free n-Hexanal, the Soybean Protein-Bound Aldehyde, and Aldehyde in the Soybean Extract.

Line 1 , the soybean extract $(1: 5 \mathrm{w} / \mathrm{v})$ before gel filtration; line 2 , the gel-filtered extract; line 3 , $n$-hexanal at the final concentration of $2.4 \mu \mathrm{m}$. The samples were appropriately diluted so that the aldehyde level was the same as that of $n$-hexanal. The reaction was followed spectrophotometrically as described in Materials AND Methods. 0.008 unit of ALDH was used. was oxidized more slowly than the bound aldehyde, although the extract contains both free and bound aldehydes. There may be an inhibitor in the extract, which is removed by gel filtration.

Fujimaki et $a l^{4)}$ and Noguchi et $a l^{5)}$ have reported that proteolytic digestion of the soybean protein loosens the interaction between the protein and aldehyde, resulting in the complete removal of aldehyde from the soybean protein preparation. We investigated if proteolytic digestion of the soybean protein increased the amount of aldehyde oxidized by ALDH. The gel filtered extract prepared by passing extract through a Sephadex G-50 column was incubated with pepsin at $\mathrm{pH}$ 1.6. At intervals, aliquots were taken out to follow the proteolytic digestion by the ninhydrin method and to measure the amount of aldehyde with ALDH after neutralization of the aliquot. As shown in Fig. 5, proteolytic digestion re-

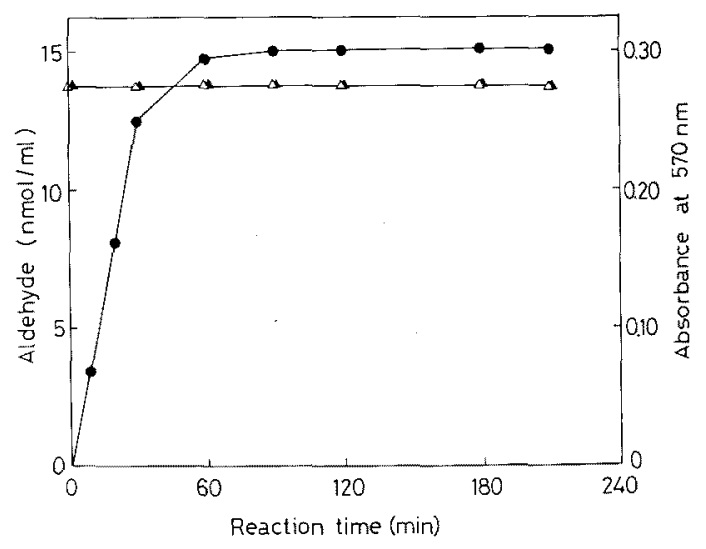

FIG. 5. Effect of Pepsin Digestion on the Aldehyde Level in the Soybean Protein Solution.

The gel-filtered extract was obtained as described in Fig. 2. It was subjected to digestion with pepsin at $25^{\circ} \mathrm{C}$. Final concentrations of the soybean protein and pepsin in the incubation mixture were $12.4 \mathrm{mg} / \mathrm{ml}$ and $1.52 \mathrm{mg} / \mathrm{ml}$, respectively. At intervals, an aliquot was neutralized to measure aldehyde and another aliquot was taken out to follow the proteolytic digestion of the soybean protein (see MATERIALS AND Methods). $(\boldsymbol{\Lambda}, \triangle)$ Concentrations of aldehyde. Aldehyde was measured with bovine ALDH (A) or yeast enzyme $(\triangle)$. (๑) Absorbancy at $570 \mathrm{~nm}$ indicates peptides soluble in $5 \%$ trichloroacetic acid. 
ached a plateau after incubation for $90 \mathrm{~min}$. The amount of aldehyde did not increase during digestion. Similar results were obtained when yeast ALDH, instead of bovine ALDH was used for the quantification of the aldehyde. We conclude, from the various experimental results described above, that bovine liver mitochondrial and yeast ALDH oxidize aldehyde bound to the soybean protein.

We investigated whether or not the aldehyde. protein complex in the gel-filtered extract dissociates upon acid precipitation of the protein. The gel-filtered extract was acidified to precipitate the protein and the precipitated protein was dissolved in distilled water. Aldehyde in the protein solution thus obtained was measured with ALDH before and after treatment with pepsin. Table II shows the results, in-

Table II. Action of Aldehyde Dehydrogenase on Aldehyde in Gel-Filtered Extrict ANd IN ACID Precipitate of GEL-Filtered ExTract

The defatted soybean extract of $58 \mathrm{ml}(1: 5 \mathrm{w} / \mathrm{v})$ was passed through a Sephadex G-50 column (2.6× $66 \mathrm{~cm}$ ) previously equilibrated with $20 \mathrm{~mm}$ phosphate

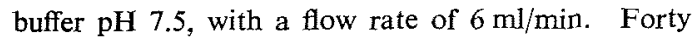
$\mathrm{ml}$ of the gel-filtered extract was subjected to acid precipitation, as described in MATERIALS AND METHons. Gel-filtered extract and the protein solution prepared with acid precipitation were subjected to digestion with pepsin. The concentration of the soybean protein was $13 \mathrm{mg} / \mathrm{ml}$ and that of pepsin was $0.24 \mathrm{mg} / \mathrm{ml}$. After the reaction was carried out at $20^{\circ} \mathrm{C}$ for $3 \mathrm{hr}$, aldehyde was measured.

\begin{tabular}{lcc}
\hline & \multicolumn{1}{c}{$\begin{array}{c}\text { Aldehyde in the samples } \\
\text { Samol/ml) }\end{array}$} \\
\cline { 2 - 3 } & \multicolumn{1}{c}{ Pepsin digestion } \\
\cline { 2 - 3 } & 17 & 17 \\
\hline $\begin{array}{l}\text { Gel-filtered extract } \\
\text { Acid precipitate of the } \\
\text { gel-filtered extract }\end{array}$ & 6.1 & 6.5 \\
\hline
\end{tabular}

cluding those for the gel-filtered extract, which was not subjected to acid precipitation. Aldehyde decreased with acid precipitate down to $35 \%$ of the original amount found in the gelfiltered extract. No difference in the amount of aldehyde was observed for samples taken before and after treatment with pepsin.
The reaction catalyzed by ADH is reversible but the equilibrium is far more favorable for the production of alcohol from aldehyde. We investigated whether $\mathrm{ADH}$ converts the soybean protein-bound aldehyde to alcohol or not. After soybean extract was incubated with horse liver $\mathrm{ADH}$ and NADH at $\mathrm{pH} 7.5$, it was subjected to gel filtration. Aldehyde in the eluted fractions was measured with ALDH. If the bound aldehyde were converted to alcohol by $\mathrm{ADH}$, no aldehyde would be found in the protein fractions. As shown in Fig. 6, the eluted protein fractions contained aldehyde whose total amount approximately corresponded to that of the protein fractions obtained by using extract untreated with $\mathrm{ADH}$. Aldehyde in the low molecular weight fractions was not measured because of high absorbancy due to NADH. The protein fraction (fraction number 6 in Fig. 6) was incubated again with NADH and ADH under similar conditions to those in Fig. 6 and then subjected to gel filtration. Again aldehyde was recovered in the protein fractions (data not shown). It appears that ADH does not act on the protein-bound

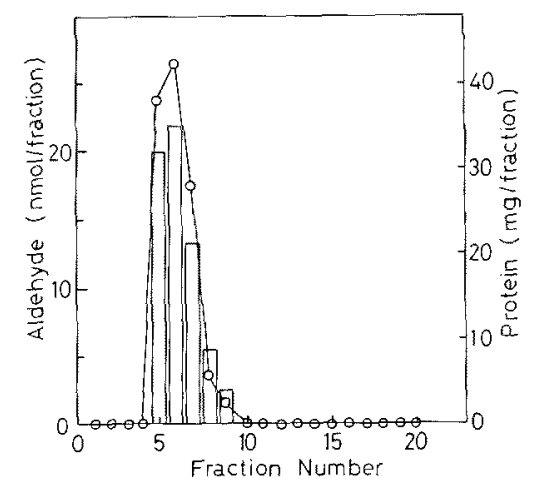

Fig. 6. Effect of Alcohol Dehydrogenase on AIdehyde in the Soybean Extract.

Defatted soybean extract was incubated with horse liver $\mathrm{ADH}$ and $\mathrm{NADH}$. The reaction contained, in a final volume of $2.2 \mathrm{ml}, 2.0 \mathrm{ml}$ of the soybean extract (1:5 w/v), 261 units of ADH, 4.5 mM NADH, and $20 \mathrm{~mm}$ phosphate buffer $\mathrm{pH} 7.5$. After incubation for $60 \mathrm{~min}$ at $25^{\circ} \mathrm{C}, 1.0 \mathrm{ml}$ of the reaction mixture was subjected to gel filtration as described in Fig. 2. Aldehyde and protein in the protein fractions were measured. A line graph is protein concentration (mg/fraction) and a bar graph is aldehyde concentration (nmol/fraction). 
aldehyde. However, ADH added in the incubation mixture before gel filtration, is eluted in the protein fractions and subsequently introduced into the reaction mixture for measuring aldehyde in the protein fractions. Therefore, it may be argued that the protein-bound aldehyde was converted into alcohol by the action of $\mathrm{ADH}$ in the incubation mixture before the gel filtration and that the alcohol in the protein fractions after gel filtration could be converted into acid via aldehyde by the coupled action of $A D H$ and ALDH in the reaction mixture for measuring aldehyde. It should be noted, however, that pyrazole, an inhibitor of $\mathrm{ADH}$, was added to the reaction mixture for measuring aldehyde. Hence it is evident that the production of NADH seen in the reaction mixture for measuring aldehyde is due to oxidation of aldehyde but not alcohol.

\section{Enzymatic removal of aldehyde in the soybean protein prepared with acid precipitation}

Results in Table II indicate that acid precipitation of soybean protein in the gel-filtered extract decreased bound aldehyde. This prompted us to test to what extent the bound aldehyde could be decreased by direct acid precipitation of the extract without gel filtration and to investigate ability of ALDH to oxidize the remaining aldehyde in the precipitate, since previous removal of most of the aldehyde by acid precipitation makes it possible to economize the amount of $\mathrm{NAD}^{+}$required for completion of the ALDH reaction. The soybean extract was repeatedly precipitated with acid, and aldehyde in the protein solutions prepared by dissolving each precipitate was measured with ALDH. As shown in Table III, aldehyde in the first precipitate decreased to about one-tenth that of the extract. Digestion of the first precipitate with pepsin did not elevate the aldehyde level. Decrease in aldehyde was observed with further precipitation and finally its level in the third precipitate lowered to the point at which reproducibility of the data was very poor with the detection sensitivity used here. Nevertheless the disagreeable flavor was certainly perceptible; the flavor was completely removed by incubating the third precipitate with ALDH and NAD ${ }^{+}$. Complete removal of the beany flavor was also achieved by incubating the first acid precipitate with $\mathrm{ALDH}$ and $\mathrm{NAD}^{+}$. In fact, aldehyde was no longer detectable in the first precipitate after incubation with ALDH and $\mathrm{NAD}^{+}$. This holds true when this first precipitate was digested with pepsin before the determination of aldehyde (data not shown). Thus aldehyde in soybean protein is greatly decreased by acid precipitation of the extract,

\section{Table III. Reduction in the Amount of Aldehyde with Acid Precipitation of Soybean Extract and Action of Aldehyde Dehydrogenase on Remaining Aldehyde}

The soybean extract of $32 \mathrm{ml}(1: 5 \mathrm{w} / \mathrm{v})$ was used without gel filtration. Preparation of the soybean protein solutions by acid precipitation of the extract was as in MATERIALS AND METHODS. Pepsin treatment was done under the conditions as in Table II except that twice the pepsin was added.

\begin{tabular}{|c|c|c|c|c|}
\hline Samples & $\begin{array}{l}\text { Aldehyde } \\
(\mathrm{nmol} / \mathrm{ml})\end{array}$ & $\begin{array}{l}\text { Protein } \\
(\mathrm{mg} / \mathrm{ml})\end{array}$ & $\begin{array}{c}\text { Aldehyde } \\
\text { protein } \\
(\mu \mathrm{mol} / \mathrm{g})\end{array}$ & $\begin{array}{l}\text { Green beany } \\
\text { flavor }\end{array}$ \\
\hline Extract & $170^{a}$ & 60.3 & 2.8 & yes \\
\hline \multirow[t]{3}{*}{ 1st precipitate } & $20^{a}$ & 51.8 & 0.39 & yes \\
\hline & $22^{b}$ & - & - & yes \\
\hline & Undetectable $^{c}$ & - & - & no \\
\hline 2nd precipitate & $6.3^{a}$ & 50.9 & 0.12 & yes \\
\hline 3rd precipitate & Detectable $^{a}$ & 48.3 & - & yes \\
\hline $\begin{array}{ll}a & \text { Without pep } \\
b & \text { With pepsin }\end{array}$ & & & & \\
\hline $\begin{array}{l}\text { The protein } \\
\text { ALDH }(6.2\end{array}$ & $\begin{array}{l}\text { he } 1 \text { st precipitat } \\
\text { H } 9.3 \text { for } 30 \mathrm{~min}\end{array}$ & ncubated & $\mathrm{D}^{+}(5 \mathrm{~mm})$ & (3 mM), \\
\hline
\end{tabular}


and ALDH acts on the aldehyde remaining in the precipitate.

\section{DISCUSSION}

The present work has shown that bovine liver and yeast ALDH oxidize the soybean protein-bound aldehyde into the corresponding acid, while horse liver ADH does not reduce the bound aldehyde. What different properties are there between two enzymes which may be crucial in the action of the enzyme on protein-bound aldehyde? It is unlikely that molecular size of the enzyme is critical for its accessibility to the bound aldehyde, because the molecular weight of ALDH $(215,000)^{6)}$ is greater than that of $\mathrm{ADH}(80,000) .{ }^{12)} \mathrm{Bo}-$ vine $\mathrm{ALDH}$ has very high affinities toward various kinds of aldehydes $(\mathrm{Km}=0.05 \mu \mathrm{M}$ for acetaldehyde and $K m=0.075 \mu \mathrm{M}$ for $n$ hexanal). ${ }^{6}$ Lower affinities were found with respect to yeast $\mathrm{ALDH} \quad(\mathrm{Km}=30 \mu \mathrm{M}$ for acetaldehyde and $K m=6 \mu \mathrm{M} \quad n$-hexanal). ${ }^{6}{ }^{\circ}$ Much lower affinities of horse liver ADH to aldehydes $(K m=230 \mu \mathrm{M}$ for acetaldehyde and $K m=74 \mu \mathrm{M}$ for $n$-hexanal) have been reported. ${ }^{13)}$ Thus affinities of the enzymes to aldehydes may be critical in their action on bound aldehyde. The manner in which aldehyde is bound to soybean protein is also important. Aldehyde may interact with the protein, exposing its hydrophobic hydrocarbon chain to the surface of the protein, and being recognized by the enzyme through both the aldehyde group and the hydrocarbon chain. Alternatively, aldehyde may be bound to the protein by its hydrocarbon chain being buried in the inside of the protein, into which the enzyme can not reach. The enzyme may recognize the aldehyde group alone or the aldehyde group with a short carbon chain exposed to the exterior of the protein. If the latter is the case, the enzyme with low affinity for the short-chain aldehyde, even though it has a high affinity for the long-chain aldehyde, would not easily act on the bound aldehyde. This appears to be the case for ADH. ALDH with a high affinity to aldehyde irrespective of its chain length could easily recognize the bound aldehyde and oxidize at a rate not much slower than that for free aldehyde (see Fig. 5).

It is not known if the carboxylic acid produced by the action of ALDH is released from the soybean protein. n-Hexanal added exogenously interacts with soybean protein but $n$-hexanoic acid does not (unpublished results). It is possible, however, that the carboxylic acid produced from the endogenous bound aldehyde differs from the exogenous $n$-hexanoic acid in the manner of binding to the soybean protein.

Acknowledgment. This work was supported by Grant-in-Aid for Scientific Research from The Ministry of Education, Science and Culture.

\section{REFERENCES}

1) S. Arai, M. Noguchi, M. Yamashita, H. Kato and M. Fujimaki, Agric. Biol. Chem., 34, 1569 (1970).

2) H. A. Gremli, J. Amer. Oil Chem. Soc., 51, 95A (1974).

3) M. Beyeler and J. Solms, Lebensm.-Wiss. Technol., 7, 217 (1974).

4) M. Fujimaki, H. Kato, S. Arai and E. Tamaki, Food Technol., 22, 889 (1968).

5) M. Noguchi, S. Arai, H. Kato and M. Fujimaki, J. Food Sci., 35, 211 (1970).

6) N. Takahashi, N. Kitabatake, R. Sasaki and H. Chiba, Agric. Biol. Chem., 43, 1873 (1979).

7) H. Chiba, N. Takahashi and R. Sasaki, Agric. Biol. Chem., 43, 1883 (1979).

8) H. Chiba, N. Takahashi, M. Yoshikawa and R. Sasaki, Abstracts of Papers, 5th International Congress of Food Science and Technology, Kyoto, September, 1978, p. 229.

9) R. Sasaki, N. Takahashi, M. Yoshikawa and H. Chiba, ibid., idem..

10) S. Moore and W. H. Stein, J. Biol. Chem., 211, 907 (1954).

11) O. H. Lowry, N. J. Rosebrough, A. L. Farr and R. J. Randall, ibid., 193, 265 (1951).

12) A. Ehrenberg and K. Dalziel, Acta Chem. Scand., 12, 465 (1958).

13) R. Pietruszko, K. Crawford and D. Lester, Arch Biochem Biophys., 159, 50 (1973). 